\title{
The role and importance of the European Union and the WHO (World Health Organization) in ensuring social safety during the COVID-19 pandemic
}

\author{
Magdalena Molendowska
}

Ph.D., Institute of Safety Sciences, Faculty of Law and Social Sciences, Jan Kochanowski University, Kielce, Poland. Email: magdalena.molendowska@ujk.edu.pl

Keywords

WHO, Social Safety, COVID-19.

Article History

Received on $2^{\text {nd }}$ November 2021

Accepted on $15^{\text {th }}$ November 2021

Published on $25^{\text {th }}$ November 2021

Cite this article

Molendowska, M. (2021). The role and importance of the European Union and the WHO (World Health Organization) in ensuring social safety during the COVID-19 pandemic. Humanities \& Social Sciences Reviews, 9(6), 3439. https://doi.org/10.18510/hssr.2021.966

Copyright @Author

Publishing License

This work is licensed under a Creative Commons Attribution-Share Alike 4.0 International License

\section{Abstract}

Purpose of the study: The object of the analysis is to evaluate the effectiveness of the measures taken by international organizations in the fight against the COVID-19 pandemic and thus to assess the effectiveness in ensuring public security. Two very important organizations were chosen for the analysis - the European Union, whose competences resulting from treaty provisions do not directly concern health, and in contrast - the World Health Organization (WHO), which was established to promote, ensure, and protect health.

Methodology: The paper was prepared based on critical analysis of literature and the uncontrolled observation method.

Main findings: The methods, forms of action and measures adopted to combat the pandemic, both by the EU and the WHO, cannot be described as fully effective. This was due to many reasons, different for both organizations, including lack of experience, adequate preparation, response time, information flow, access to vaccines, etc. Nevertheless, both organizations played a very important role. The EU has played and continues to play an integrating role, providing a sense of solidarity in the fight against the pandemic. The WHO, in turn, acts as an authority in the medical field, its guidelines and recommendations are credible to most of the international community.

Application of the study: The presented article refers to the issue of security in a crisis situation, which is the COVID-19 pandemic. It implies reflections in such scientific fields as, among others security, healty and psychology. In addition, the study may be relevant to the discussion on strengthening the competences of the EU and WHO.

Original/Novelty of the study: The subject matter addressed is very timely, in fact we are all caught up in the problem identified. The fight against the pandemic is still on and the current assessment is probably only a fraction of the research that can be fully presented once the pandemic is over. Therefore, the article may serve as an inspiration to continue deliberations about this topic. Perhaps only the invention of an effective drug, rather than a vaccine for COVID-19, can be declared a battle won. 


\title{
Rola i znaczenie Unii Europejskiej oraz Światowej Organizacji Zdrowia w zapewnieniu bezpieczeństwa społecznego podczas pandemii COVID-19
}

\author{
Magdalena Molendowska \\ Dr, Instytut Nauk o Bezpieczeństwie, Wydział Prawa i Nauk Społecznych, Uniwersytet Jana Kochanowskiego w \\ Kielcach, Polska. \\ E-mail: magdalena.molendowska@ujk.edu.pl
}

\author{
Slowa kluczowe \\ Swiatowa Organizacja Zdrowia, \\ bezpieczeństwo społeczne, COVID-19 \\ Historia artykułu \\ Otrzymano 2 listopada 2021 \\ Przyjęta 15 listopada 2021 \\ Opublikowano 25 listopada 2021
}

\section{Cite this article}

Molendowska, M. (2021). The role and importance of the European Union and the WHO (World Health Organization) in ensuring social safety during the COVID-19 pandemic. Humanities \& Social Sciences Reviews, 9(6),

\section{Copyright @Author}

Publishing License

This work is licensed under a Creative Commons Attribution-Share Alike 4.0 International License

\section{Streszczenie}

Cel badawczy: przedmiotem analizy jest ocena skuteczności działań organizacji międzynarodowych w walce $\mathrm{z}$ pandemią COVID-19 i tym samym ocena ich skuteczności w zapewnieniu bezpieczeństwa społecznego. Do analizy wybrane zostały dwie bardzo ważne organizacje, jedna, której kompetencje wynikające $\mathrm{z}$ zapisów traktatowych nie dotyczą bezpośrednio zdrowia - Unia Europejska oraz druga dla kontrastu, która została powołana, aby promować, zapewniać i chronić zdrowie - Światowa Organizacja Zdrowia (WHO, World Health Organization).

Metodologia: artykuł przygotowano w oparciu o krytyczną analizę literatury oraz metodę obserwacji niekontrolowanej.

Glówne wnioski: metody, formy działania oraz środki przyjęte do walki z pandemią, zarówno przez UE, jak i WHO nie do końca możemy określić jako skuteczne. Wynikało to z wielu przyczyn, różnych dla obu organizacji, m.in. z braku doświadczenia, odpowiedniego przygotowania, czasu reakcji, przepływu informacji, dostępu do szczepionek itp. Niemniej jednak obie organizacje odegrały bardzo ważną rolę. UE - pełniła i pełni rolę integrującą, zapewnia poczucie solidarności $\mathrm{w}$ walce $\mathrm{z}$ pandemią. Z kolei WHO pełni rolę autorytetu w obszarze medycznym, jej wytyczne oraz rekomendacje są wiarygodne dla większości społeczności międzynarodowej.

Zastosowanie badania: prezentowany artykuł odnosi się do problematyki bezpieczeństwa w sytuacji kryzysowej, jaką jest pandemia COVID-19. Implikuje refleksje $\mathrm{w}$ takich dziedzinach nauki jak m.in. bezpieczeństwo, zdrowie i psychologia. Ponadto badanie może mieć znaczenie dla dyskusji na temat wzmocnienia kompetencji UE i WHO.

Oryginalność badań: podjęta tematyka jest bardzo aktualna, w zasadzie wszyscy jesteśmy uczestnikami wskazanego problemu. Walka z pandemią nadal trwa i obecna ocena stanowi zapewne tylko wycinek badań, które będzie można w pełni przedstawić dopiero po zakończeniu pandemii. Dlatego też artykuł może inspirować do kontynuacji rozważań na ten temat. Być może dopiero wynalezienie skutecznego leku, a nie szczepionki na COVID-19, będzie można ogłosić jako wygraną walkę.

\section{Wprowadzenie}

Bezpieczeństwo każdego człowieka sprowadza się do trzech wymiarów, które w strategii bezpieczeństwa większości państw podzielone są na trzy grupy interesów. Pierwsza grupa to tzw. interesy żywotne czy też egzystencjalne, które zapewniają przetrwanie jednostki i państwa. Druga grupa, to interesy ważne, które wiążą się $\mathrm{z}$ bezpieczeństwem ekonomiczno-społecznym, i których realizacja wpływa bezpośrednio na poziom życia obywateli. Trzecia grupa interesów, z punktu widzenia zwykłego obywatela ma najmniejsze znaczenie, obejmują one m.in. budowę znaczenia państwa na arenie międzynarodowej (Zajas, Zięba, Skrzyp, s. 2-3). W państwach wysoko rozwiniętych pierwsza grupa interesów bezpieczeństwa już od dawna traktowana jest jako pewnego rodzaju aksjomat. Dopiero pandemia COVID-19 przewartościowała zarówno system bezpieczeństwa krajowego, jak i zbiorowego. Kwestie egzystencji, przetrwania i zdrowia stały się kluczowym problemem. Państwa na całym świecie podjęły działania zapobiegawcze oraz takie, które miały zapewnić skuteczną walkę $\mathrm{z}$ wirusem. Działania te miały zarówno charakter indywidualny, jak $\mathrm{i}$ w ramach zinstytucjonalizowanej międzynarodowej współpracy. Warto podkreślić, że wypracowanie wspólnej wizji bezpieczeństwa jest możliwe tylko dzięki świadomości faktu, że wiele obecnych wyzwań jest w rzeczywistości wynikiem pewnych wspólnych zagrożeń i słabych punktów, które wymagają rozwiązań tego samego rodzaju.

\section{Unia Europejska w walce $\mathrm{z}$ pandemią}

Pandemia COVID-19 obnażyła wiele słabości wspólnego, kooperatywnego bezpieczeństwa, które miało być zapewnione w ramach organizacji międzynarodowych. Z problemem pandemii słabo poradziła sobie Unia Europejska (UE), wprowadzanie wspólnych rozwiązań, czy wytycznych nie bardzo się sprawdzało. Okazało, że kwestia walki z pandemią była i jest prawie wyłączną domeną państw członkowskich. Niektóre kraje UE miały również pretensje dotyczące, ich 
zdaniem, niesprawiedliwej dystrybucji szczepionek: „Austria, Czechy, Słowenia, Bułgaria i Łotwa wezwały do zwołania szczytu UE w celu omówienia 'ogromnych dysproporcji' w dystrybucji szczepionek" (Niesprawiedliwy podział szczepionek. Kraje UE chca szczytu, 2021). Zanim jednak krytycznie ocenimy działania UE w walce z pandemią, należy wziąć pod uwagę fakt, że Unia Europejska nigdy nie miała w swych kompetencjach tego typu działań, być może po prostu ich nie przewidziano. Pandemia COVID-19, jej rozmiar i skutki tak naprawdę zaskoczyły cały świat. To na pewno był ogromny test dla UE z zakresu zarządzania kryzysowego. Warto podkreślić, że UE posiada bardzo dobrze zbudowany system wczesnego ostrzegania w obrębie zarządzania kryzysowego. Jednym z elementów tego systemu, który odnosi się do zagrożeń epidemicznych jest EWRS (The Early Warning and Response System) - system wczesnego ostrzegania i alarmowania, którego podstawy prawne stanowią: decyzja Komisji i Parlamentu Europejskiego nr 2119/98/EC z dnia 24 września 1998 r. o stworzeniu skomputeryzowanego systemu kontroli epidemiologicznej UE oraz decyzja Komisji nr 2000/57/EC z dnia 24 września 1998 r. (Górski, Kołodziejczyk, Molendowska, Ostrowska, 2019, s. 31.) Co do samego ostrzeżenia dotyczącego pandemii COVID-19, to dotarło ono bardzo wcześnie, jednak w kolejnych fazach: zapobiegania oraz reagowania, podjęte kroki okazały się mało skuteczne, być może wynikały one z braku doświadczenia $\mathrm{z}$ tego typu zagrożeniem. Na obronę UE można przytoczyć fakt, że tak naprawdę żaden kraj czy inna organizacja międzynarodowa nie poradziły sobie $\mathrm{z}$ tym problemem lepiej. Na pewno Unia bardzo poprawnie zareagowała w ostatnim czasie oferując pomoc finansową państwom członkowskim w radzeniu sobie z gospodarczymi oraz społecznymi skutkami pandemii. Uruchomiono m.in. NextGenerationEU - tymczasowy instrument odbudowy gospodarczej o wartości ponad 800 mld euro. Długoterminowy budżet UE w połączeniu z NextGenerationEU (NGEU), to największy pakiet środków, jaki został dotychczas sfinansowany w Europie. Wynosząca łącznie kwota 2,018 bln euro w cenach bieżących posłuży odbudowie Europy po pandemii COVID-19 (Plan odbudowy dla Europy). Ponadto w dniach 21-22 października 2021 r. przywódcy UE zebrani w Brukseli rozmawiali o niektórych kluczowych aspektach reakcji na koronakryzys. Uznali, że kampanie szczepień w całej Europie przyczyniły się do znacznych postępów, niemniej jednak wezwali do większych wysiłków, aby przezwyciężać sceptycyzm szczepionkowy, między innymi poprzez walkę z dezinformacją (Pandemia COVID-19 i reakcja UE).

Ta krótka analiza reakcji Unii Europejskiej na pandemię COVID-19 posłuży jako pewnego rodzaju porównanie. Jak już zastało podkreślone, UE nigdy nie była organizacją, dla której kwestie z zakresu bezpieczeństwa zdrowotnego miały priorytetowe znaczenie. Od czasu powstania Europejskiej Wspólnoty Węgla i Stali kluczową rolę odgrywało bezpieczeństwo ekonomiczne, gospodarcze i społeczne w sensie zapewnienia odpowiedniego poziomu i jakości życia. Oczywistym jest, że UE już od czasu przygotowania projektu Europejskiej Wspólnoty Obronnej z 1952 r. pretendowała do tego, aby mieć również znaczący udział w bezpieczeństwie stricte militarnym. Jednak jak do tej pory to zadanie nie do końca się powiodło. Mimo wszystko, już w pierwszej połowie lat dziewięćdziesiątych XX w. UE zaczęła rozbudowywać swój potencjał z zakresu bezpieczeństwa wewnętrznego i zewnętrznego oraz stworzyła system zarządzania kryzysowego, wyposażając go w odpowiednie mechanizmy, instrumenty finansowe oraz tworząc narzędzia wczesnego ostrzegania (Legucka, 2009, s. 140-142). Oceniając skuteczność UE w walce z pandemią COVID-19 warto ją zestawić z działaniami innej organizacji, która w zasadzie została stworzona do tego, aby zapewniać bezpieczeństwo zdrowotne. Taką organizacją jest Światowa Organizacja Zdrowia (WHO, World Health Organization).

\section{Metody i sposoby walki z pandemią zastosowane przez WHO}

Jako pierwsze próby stworzenia międzynarodowej współpracy z zakresie bezpieczeństwa zdrowotnego można potraktować zainicjowane w 1851 r. w Paryżu tzw. konferencje sanitarne. Pierwsza z nich dotyczyła właśnie walki z chorobami epidemicznymi, jednym z największych zagrożeń, które wówczas odnotowywano była cholera. Międzynarodowa Konferencja Sanitarna miała zasięg ogólnoświatowy i działała do 1938 r. Warto podkreślić, że w zakresie bezpieczeństwa zdrowotnego to Francja wiodła prym i również w Paryżu w 1907 r. powołano Międzynarodowe Biuro Higieny Publicznej, którego funkcje przejęła WHO (Latoszek, Proczek, 2006, s. 129). Światowa Organizacja Zdrowia została powołana w 1948 r. jako wyspecjalizowana organizacja ONZ. W dniach od 19 czerwca do 22 lipca 1946 r. odbyła się w Nowym Jorku Międzynarodowa Konferencja Zdrowia zorganizowana przez Radę GospodarczoSpołeczną ONZ, podczas której przygotowano statut WHO. Opracowując ten dokument opierano się na założeniach Karty Narodów Zjednoczonych, a dokładnie na artykule 55, w którym zapisano poparcie dla rozwiązywania międzynarodowych zagadnień z zakresu zdrowia (Karta Narodów Zjednoczonych, art. 55). Głównym celem WHO jest „uzyskanie przez wszystkich ludzi możliwie najwyższego poziomu zdrowia” (Latoszek, Proczek, 2006, s. 129). Zdrowie zaś zostało zdefiniowane jako „stan pełnego fizycznego, psychicznego i społecznego dobrostanu, a nie jedynie brak choroby lub kalectwa. [...] Zdrowie wszystkich narodów ma fundamentalne znaczenie dla osiągnięcia pokoju i bezpieczeństwa i jest uzależnione od jak najpełniejszej współpracy jednostek" (WHO Basic Documents, 2014, s. 1).

W grudniu 2019 r. nowy koronawirus zespołu ostrej niewydolności oddechowej 2 (SARS-CoV-2) spowodował wybuch choroby koronawirusowej COVID-19, a wynikająca z tego pandemia spowodowała powszechne problemy zdrowotne oraz zakłócenia społeczne i gospodarcze. Do tej pory na COVID-19 zmarło ponad 4 miliony ludzi na całym (stan na 2021 r.) (Cui, Wang, Wei, 2021, s. 222-223). WHO ogłosiło nową chorobę COVID-19 jako globalną pandemię w dniu 11 marca 2020 r. (Ariya, Karimi, Abolghasemi, Hematdar, Naghizadeh, Moradi, Barati-Boldaji, 2021, s. 1.)

WHO od samego początku wybuchu pandemii stawiała przede wszystkim na szczepionki. Od czerwca 2021 r. istnieją cztery główne kategorie szczepionek: mRNA, z wektorem adenowirusowym, inaktywowane szczepionki wirusowe oraz szczepionki z rekombinowanych białek. Szczepionki zostały wyprodukowane przez 23 firmy i instytucje badawcze z 8 krajów (Patel, Patel, Suthar, 2021, s. 155-164). Światowa Organizacja Zdrowia jako przykład w walce z pandemią 
wskazuje Izrael, w którym tylko 17\% obywateli nie zaszczepiło się, w tym głównie dzieci do 12 roku życia. WHO podaje, że obecnie ponad 6,5 miliona ludzi na całym świecie zostało zaszczepionych (Cui, Wang, Wei, 2021, s. 222$\underline{223}$.

Ponadto należy zwrócić uwagę, że od początku wybuchu pandemii jedną z najistotniejszych kwestii, oprócz wynalezienia skutecznej i bezpiecznej szczepionki, było właściwe przekazywanie informacji o stanie zagrożenia. Odpowiedni przepływ informacji wiąże się z postrzeganiem bezpieczeństwa. Według Daniela Freia, postrzeganie bezpieczeństwa można przedstawić za pomocą czerech stanów (Zięba, 1997, s. 4-5; Frei, 1977, s. 19-21):

- stan braku bezpieczeństwa, występuje wtedy, gdy istnieje duże zagrożenie zewnętrzne, a postrzeganie tego zagrożenia jest właściwe i realne;

- stan obsesji, występuje, gdy nieznaczne zagrożenie postrzegane jest, jako duże;

- stan fałszywego bezpieczeństwa, występuje wówczas, gdy poważne zagrożenie zewnętrzne jest postrzegane, jako niewielkie;

- stan bezpieczeństwa, jest wtedy, gdy zagrożenie zewnętrzne jest niewielkie, a jego postrzeganie jest prawidłowe.

Szczególnie niebezpieczne w każdej sytuacji kryzysowej, w tym również podczas pandemii, są dwa rodzaje postrzegania bezpieczeństwa: fałszywe i obsesji. Z fałszywym obrazem stanu zagrożenia, w początkowej fazie wybuchu pandemii, mieliśmy do czynienia przede wszystkich w krajach reżimowych. Przywódcy tych krajów utrzymywali, że im pandemia nie zagraża, a nawet jeśli są pojedyncze przypadki zachorowań, to bez problemu sobie z nimi poradzą. Przeciwieństwem stanu fałszywego, jest stan obsesji, który może doprowadzić do masowej paniki. Zatem informowanie o ryzyku było i jest kluczowym elementem interwencji w zakresie zdrowia publicznego podczas epidemii. W miarę rozwoju pandemii koronawirusa pod koniec 2019 r. Światowa Organizacja Zdrowia (WHO) była liderem w opracowywaniu strategii komunikacji ryzyka. WHO przedstawiła szereg działań mających na celu umożliwienie społeczeństwu korzystania ze zweryfikowanych i podanych we właściwym czasie informacji na temat zachowań związanych z zapobieganiem COVID-19 (Varghese, Sabat, Neumann-Bo"hme, Schreyo"gg, Stargardt, Torbica, van Exel, Barros, 2021, s. 1). Informowanie o ryzyku jest kluczem do lepszego poznania i przestrzegania środków zapobiegawczych zarówno $\mathrm{w}$ normalnych czasach, jak i w nagłych wypadkach zdrowotnych. Brak właściwej komunikacji może skutkować utratą zaufania, szkodą dla gospodarki i utratą życia. Światowa Organizacja Zdrowia była na pierwszej linii frontu w swoich działaniach mających na celu powstrzymanie i złagodzenie rozprzestrzeniania się pandemii COVID-19. Sieć informacyjna WHO ds. epidemii (lub EPI-WIN) została wprowadzona, gdy COVID-19 został uznany za stan wyjątkowy o zasięgu międzynarodowym, tj. w dniu 30 stycznia 2020 r. EPI-WIN zapewnia dostosowanie informacji i wskazówek do określonych grup docelowych. Głównym celem było zwiększenie świadomości społecznej na temat środków zapobiegawczych przeciwko COVID-19 poprzez łatwe do zrozumienia komunikaty behawioralne za pomocą infografiki i filmów zamieszczanych na stronie WHO. Kolejną inicjatywą WHO w zakresie komunikacji ryzyka była współpraca w ramach Globalnej Sieci Ostrzegania i Reagowania na Epidemię (GOARN). Sieć obejmuje 250 instytutów technicznych na całym świecie, które aktywnie uczestniczyły we współtworzeniu i wdrażaniu komunikatów o ryzyku, tak aby dostosować je do lokalnego kontekstu. Ponadto WHO podjęła szereg innych innowacyjnych kroków w celu poprawy komunikacji ryzyka podczas pandemii. Nawiązała współpracę z firmami zajmującymi się mediami społecznościowymi i Google, aby upewnić się, że wszelkie zapytania związane z COVID-19 kierują użytkownika na strony WHO. Światowa Organizacja Zdrowia wprowadziła też internetowy kurs szkoleniowy na temat COVID-19 i współpracowała ze znanymi ludźmi (m.in. gwiazdami telewizji), którzy mogli wpłynąć na odpowiednie postawy wśród swoich fanów (Varghese, Sabat, Neumann-Bo"hme, Schreyo"gg, Stargardt, Torbica, van Exel, Barros, 2021, s. 2).

Kolejną inicjatywą WHO w zakresie walki z pandemią było promowanie odpowiednich zachowań wśród migrantów. Globalizacja, duża mobilność ludzi, w tym także migracja (legalna i nielegalna) mają duży wpływ na rozprzestrzenianie się COVID-19. W celu zwrócenia uwagi na zwiększoną podatność uchodźców i migrantów na zachorowania, WHO rozpoczęła badanie ApartTogether, było to pierwsze badanie wpływu społecznego pandemii COVID-19 na uchodźców i migrantów na całym świecie. Ponadto w czerwcu $2021 \mathrm{r}$. WHO przedstawiła pierwszy raport z serii Global Evidence Review on Health and Migration (GEHM). W raporcie wskazano, jak wiele polityk wrażliwych na uchodźców i migrantów współistniało z praktykami dyskryminacyjnymi podczas pandemii COVID-19, które zagrażają prawom uchodźców i migrantów. Zdaniem WHO, krajowe reakcje na pandemię COVID-19 wymagają wzmocnienia systemu opieki zdrowotnej i opracowania krajowych planów wdrażania szczepień, które przewidują szczepienia zgodnie z prawami człowieka i zasadami etycznymi. WHO współpracuje z partnerami międzynarodowymi, aby scharakteryzować bariery społeczne, ekonomiczne i kulturowe, z jakimi borykają się uchodźcy i migranci w dostępie do szczepionek oraz monitoruje i ocenia politykę szczepień. Ponadto WHO współpracuje z siecią ONZ ds. migracji, aby zapewnić, migrantom objęcie krajowymi programami szczepień przeciwko COVID-19 (World Health Organization, 31 August 2021).

Analizując działalność WHO w zakresie walki z pandemią, można wysunąć tezę, że w zakresie informacyjnym WHO spełniło swoje zadania. Co więcej, kraje, a przede wszystkim społeczność międzynarodowa oczekiwała jasnego przekazu na temat bezpieczeństwa pojawiających się szczepionek i WHO odegrała rolę autorytetu w tym obszarze. Jednak nie wszystkie kraje były zadowolone z działań WHO w dobie pandemii. Szczególnego znaczenia nabrała reakcja prezydenta USA Donalda Trumpa, który oficjalnie wycofał swój kraj ze Światowej Organizacji Zdrowia. Zarzucił jej 
m.in. spóźnioną reakcję na pandemię koronawirusa. Budżet WHO został tym sposobem uszczuplony o ok. 15\% wpływów. Ponadto Trump oskarżył Chiny o wywieranie presji na WHO i nieprzesyłanie obowiązkowych reportów.

Nie ulega wątpliwości, że wszystkie kraje powinny zwiększyć swój poziom gotowości, czujności i reagowania w celu identyfikacji, zarządzania i opieki nad nowymi przypadkami COVID-19. Państwa powinny przygotować się do reagowania na różne scenariusze dotyczące zdrowia publicznego, uznając, że nie ma jednego uniwersalnego podejścia do zarządzania przypadkami i epidemiami COVID-19. Istnieje siedem scenariuszy transmisji COVID-19: brak przypadków, przypadki sporadyczne, skupiska przypadków i cztery poziomy transmisji w społeczności. Kraje powinny oceniać scenariusze transmisji na poziomie niższym niż krajowy, tj. na poziomie regionalnym (w przypadku Polski np. na poziomie województw). Wszystkie państwa powinny ocenić swoje ryzyko i szybko wdrożyć niezbędne środki na odpowiednią skalę, aby ograniczyć zarówno transmisję COVID-19, jak i skutki gospodarcze, publiczne i społeczne (World Health Organization, 27 May 2021).

\section{Podsumowanie}

Oceniając skuteczność UE i WHO należy również odpowiedzieć na pytanie na ile rekomendowane przez nie środki zapobiegawcze są wdrażane i przestrzegane $\mathrm{w}$ poszczególnych krajach? Zarówno UE, jak i WHO podkreślają konieczność:

- utrzymania działań prewencyjnych, m.in. poprzez zachowanie zalecanego dystansu społecznego, zakrywanie nosa i ust w miejscach, w których jest to wymagane;

- testowania, które daje możliwość wczesnego wykrywania przypadków i izolowanie chorych, kwarantanna osób, które miały kontakt z osobą zakażoną, śledzenie kontaktów;

- kontroli ognisk choroby i podejmowanie działań mających na celu ograniczenie transmisji wirusa i dalsze rozprzestrzenianie się choroby;

- nadzoru epidemicznego, monitorowania zagrożeń i polityki szybkiego reagowania oraz przyjęcia polityki uzależnionej od ryzyka, tzw. podejście risk-based approach (Niemcy, UK);

- decentralizacji działań w zakresie prowadzonej polityki walki z pandemią - delegowanie zadań na szczeble regionalne;

- ochrony grup wysokiego ryzyka - m.in. osoby starsze, osoby z chorobami przewlekłymi (Niemcy, UK);

- kontroli podróżujących;

- edukacji społeczeństwa - kampanie edukacyjne dostarczające społeczeństwu opartych na dowodach informacji na temat COVID-19;

- współpracy międzynarodowej i wymiany doświadczeń (platformy internetowe, bazy danych);

- polityki proszczepiennej;

- zapewnienia ciągłości świadczenia podstawowych usług zdrowotnych.

W większości krajów UE powyższe rekomendacje są oficjalnie stosowane. Problemy z ich egzekwowaniem wynikają z nieostrych przepisów prawnych przyjętych przez państwa na czas pandemii lub z pewnego rodzaju „rozluźnienia” zachowań społecznych, które są efektem „,przyzwyczajenia” się do pandemii lub „zmęczenia” restrykcjami. Nawet jeśli z perspektywy czasu, działania UE, jak i WHO nie do końca jesteśmy w stanie ocenić jako w pełni skuteczne w walce z pandemią, to mimo wszystko, uważam, że obie organizacje, na właściwym sobie poziomie i w zakresie, odegrały dużą rolę. Z punktu widzenia bezpieczeństwa międzynarodowego niezwykle ważna jest solidarność, wspólne działania i wsparcie. Tego typu wsparcie dawała i daje Unia Europejska wszystkim państwom członkowskim, które dzięki temu mają poczucie, że $\mathrm{w}$ walce $\mathrm{z}$ pandemią nie są same. Z kolei WHO pełniła i pełni rolę autorytetu w zakresie stosowanych rozwiązań medycznych, w tym w szczególności zapewnia kluczowe informacje w zakresie bezpieczeństwa nowych szczepionek.

\section{Bibliografia}

1. Ariya, M. J. Karimi, Abolghasemi, S. Hematdar, Z., Naghizadeh, M. M., Moradi, M., Barati-Boldaji, R. (2021). Food insecurity arises the likelihood of hospitalization in patients with COVID-19, w: Scientific Reports, $\mathrm{Nr} 11$, ss. 1-9. https://doi.org/10.1038/s41598-021-99610-4

2. Cui, X., Wang, P., Wei, Z. (2021). Emergency use of COVID-19 vaccines recommended by the World Health Organization (WHO) as of June 2021, w: Drug Discoveries \& Therapeutic, Nr 15(4), ss. 222-224. https://doi.org/10.5582/ddt.2021.01064

3. Frei, D. (1977), Sicherheit. Grundfragen der Weltpolitik, Stuttgar: Kohlhammer Mainz, ss. 133.

4. Górski, P., Kołodziejczyk, R., Molendowska, M., Ostrowska, M. (2019). System zarzadzania kryzysowego w Polsce w kontekście czlonkostwa w Unii Europejskiej, Toruń: Wydawnictwo Adam Marszałek, ss. 309.

5. Karta Narodów Zjednoczonych, Statut Międzynarodowego Trybunału Sprawiedliwości i Porozumienie ustanawiajace Komisję Przygotowawcza Narodów Zjednoczonych, Dz.U. 1947 nr 23 poz. 90. 
6. Latoszek, E. i Proczek, M. (2006), Organizacje międzynarodowe we współczesnym świecie, Warszawa: Wydawnictwo Elipsa, ss. 672.

7. Legucka, A. (2009). Podstawy normatywne reagowania kryzysowego Unii Europejskiej, w: Gryz, J. (red.), System reagowania kryzysowego Unii Europejskiej. Struktura-Charakter-Obszary, Toruń: Wydawnictwo Adam Marszałek, ss. 424.

8. Niesprawiedliwy podziat szczepionek. Kraje UE chca szczytu (13.03.2021). w: Rzeczpospolita, https://www.rp.pl/swiat/art229991-niesprawiedliwy-podzial-szczepionek-kraje-ue-chca-szczytu [dostęp 31.10.2021].

9. Pandemia COVID-19 i reakcja UE, https://www.consilium.europa.eu/pl/policies/coronavirus/\# [dostęp 31.10.2021].

10. Patel, Sh. P., Patel, G. S., Suthar, J. V. (2021). Inside the story about the research and development of COVID19 vaccines, w: Clin Exp Vaccine Res, Nr 10, ss. 154-170. https://doi.org/10.7774/cevr.2021.10.2.154

11. Plan odbudowy dla Europy, https://ec.europa.eu/info/strategy/recovery-plan-europe_pl [dostęp: 31.10.2021].

12. Varghese, N. E., Sabat, I., Neumann-Bo“hme, S., Schreyo“gg, J., Stargardt, T., Torbica, A., van Exel, J., Barros, P. P., Brouwe, W. (2021). Risk communication during COVID-19: A descriptive study on familiarity with, adherence to and trust in the WHO preventive measures, w: PLOS ONE, Ss. 1-15. https://doi.org/10.1371/journal.pone.0250872

13. WHO Basic Documents, 48 Edition, Printed in Italy 2014, ss. 224.

14. World Health Organization. (27 May 2021). Critical preparedness, readiness and response actions for COVID19, https://www.who.int/publications/i/item/critical-preparedness-readiness-and-response-actions-for-COVID19 [dostęp 01.11.2021].

15. World Health Organization. (31 August 2021). Promoting the health of refugees and migrants during COVID19 pandemic, https://www.who.int/activities/promoting-the-health-of-refugees-and-migrants-during-COVID19-pandemic [dostęp 01.11.2021].

16. Zajas, S., Zięba, R., Skrzyp, J. Wnioski: zdefiniowanie i prioretyzacja interesów narodowych oraz określenie wypływajacych $z$ nich możliwych $i$ pożądanych (rekomendowanych) celów strategicznych Rzeczypospolitej Polskiej $w$ dziedzinie bezpieczeństwa, ss. 1-15, https://www.bbn.gov.pl/download.php?s=1\&id=7585 [dostęp 19.05.2021].

17. Zięba, R. (1997). Kategoria bezpieczeństwa w nauce o stosunkach międzynarodowych, [w:] Zięba, R., Bobrow, D. B., Haliżak, E. (red.), Bezpieczeństwo narodowe $i$ międzynarodowe u schyłku XX wieku, Warszawa: Wydawnictwo Naukowe SCHOLAR, ss. 575. 